\title{
Czy doping genetyczny zmieni sportowe prawa?'1
}

\section{Is gene doping going to change the sports law?}

From time to time the public is informed about the start of the sporting struggles. Championship, Olympics, qualifications and eliminations are events that have become part of individual media centers programs. For many years, during such events there is a discussion about doping. It is widely criticized as an example of violation of fair play principle, which has been present for many generations in sport. This subject was completed in recent years on discussions related to the application of gene doping.

There is currently no verified information indicating that any of the countries apply similar techniques to assist athletes. Whether similar action would be unethical? Does gene doping violate the principles of fair play? Did the law define the term of gene doping?

In the proposed speech there will be taken reflection on these topics. It will be carried out by the use of appearing during a sports event media materials relating to the abovementioned issues. It will be also assisted by fiction literature, raising in recent years the topic of gene doping.

\section{Wprowadzenie}

W roku 2013 pojawiła się na polskim rynku wydawniczym książka autorstwa Robina Cooka pt. Nano. Autor ten - z wyksztalcenia lekarz - uznawany jest obecnie za jednego najbardziej popularnych amerykańskich pisarzy. W przywołanej powieści czytelnik przeniesiony zostaje do małej miejscowości w pobliżu Denver (USA). W miejscu tym swoją pierwszą pracę rozpoczyna młoda lekarka, Pia Grazdani. Osoba ta prowadzi w tytułowej firmie „Nano” badania dotyczące mechanicznego wsparcia u człowieka procesu oddychania. W procesie tym kluczową rolę

1 Projekt sfinansowany ze środków Narodowego Centrum Nauki przyznanych na podstawie decyzji numer DEC-2013/10/E/HS5/00157. 
mają odgrywać mikroskopijne bioroboty; ich działanie ma wpływać na szybsze dostarczenie tlenu do poszczególnych komórek, mięśni oraz narządów. Czytelnik, zapoznając się z treścią książki, w pewnym momencie może się zorientować, iż w firmie prowadzone są również inne doświadczenia. Jej właściciel, Zachary Berman, postanowił wyniki prac dr Grazdani wykorzystać dla celów ulepszenia zdolności oraz wydolności sportowców. Badaniami zainteresował się rząd jednego z mocarstw azjatyckich. Do eksperymentów tych dołączeni zostają chińscy „ochotnicy". Są to w istocie osoby, które wcześniej zostałyby skazane na karę śmierci. $\mathrm{Na}$ bieżni oraz torze kolarskim, pod czujnym nadzorem testują oni, jak wyniki eksperymentów z biorobotami, wpłyną na wydolność ich organizmu. Część „ochotników" w trakcie badań umiera. Jak się okazuje motywacja Zacharego Bermana ma nie tylko charakter finansowy. Jego rodzice cierpieli na chorobę Alzheimera. Ojciec zmarł, a mama skierowana została do domu opieki, w którym ją regularnie odwiedzał, pomimo iż od dawna już go nie rozpoznawała. Co więcej, szef firmy „Nano" dowiedział się, że istnieje u niego wysokie genetyczne prawdopodobieństwo zachorowania na podobne schorzenie neurodegeneracyjne (Cook, 2013).

W opisanej powyżej historii Robin Cook pierwszy raz zdecydował się podjąć temat genetycznych modyfikacji, zmierzających do zwiększenia siły, wydajności oraz wydolności ludzkiego organizmu. We wcześniejszych publikacjach, między innymi w książce Mutant, skupiał się przede wszystkim na biotechnologicznych eksperymentach, których celem było udoskonalenie ludzkiej inteligencji (Kmieciak, 2013, online). Choć przywołane w tym miejscu pozycje książkowe zaliczane są do grona literatury medical-fiction, to nie ulega najmniejszej wątpliwości, iż odnoszą się one do problemów społeczno-medycznych, które z racji na rozwój nauki spotykają się z coraz żywszym zainteresowaniem. Śledząc bowiem losy bohaterów powieści Nano dostrzec można, iż postęp w naukach biomedycznych możliwy jest między innymi dzięki istotnemu wsparciu finansowemu. Wspomniane wsparcie, co warto zaznaczyć nie odnosi się jedynie celów o charakterze medyczno-zdrowotnym. Część z podobnych działań w sposób bezpośredni związana jest ze sportem, który gromadzi nie tylko zawodników, trenerów bądź też działaczy, ale również przedstawicieli świata biznesu, zainteresowanych nowymi obszarami inwestycyjnymi. Poszukując informacji dotyczących dopingu genetycznego spostrzec można, iż fakty opisywane przez Robina Cooka nie posiadają wyłącznie charakteru publicystyczno-beletrystycznego. Okazuje się bowiem, iż zarówno naukowcy, jak i dziennikarze specjalizujący się w popularyzacji nauki dostrzegają podobne tendencje, jak te opisane w książce Nano.

\section{Cel i metoda}

Celem autora pracy jest przede wszystkim wskazanie na szczególną postać zjawiska - dopingu genetycznego. Jego unikalny charakter objawia się przede wszystkim w nadal rozległym obszarze niewiedzy, jaki dostrzegamy analizując omawiane zagadnienie. Nie wiemy kto potencjalnie może podejmować podobne 
działanie. Nie znamy również szeroko komentowanych przykładów, przyłapania sportowca, u którego stwierdzono istnienie celowo zmodyfikowanych organicznych zmian. Z drugiej jednak podobne perspektywy czyli potencjalne możliwości modyfikacji ludzkiego organizmu, powodują pojawienie się licznych pytań oraz wątpliwości. W ramach operacjonalizacji procesu badawczego, zasadne jest sformułowanie najistotniejszych pytań, wokół których skupiać się będą dalsze refleksje (Apanowicz, 2002) W pierwszym rzędzie należy zastanowić się, czym $w$ istocie jest doping genetyczny? Tym samym, czy przepisy antydopingowe zdefiniowały wspomniany termin? W kolejnej części pracy należy rozważyć, jakie zagrożenia powoduje stosowanie genetycznych technik modyfikacji organizmów sportowców? W tym miejscu zasadne jest, by rozważyć, czy wspomniana forma dopingu posiadać może pozytywne elementy?

Próba sformułowania odpowiedzi na powyższe pytanie odbywać się będzie przede wszystkim poprzez podjęcie działań opartych na metodzie analizy dokumentów (Goodman, 2001). Kluczową rolę odgrywać będzie w pracy analiza medialnych materiałów (Goban-Klas, 1984). W sposób szczególny wykorzystane zostaną opinie wyrażone przez genetyka ogólnego, biologa - eksperta w tematyce dopingu, bioetyka oraz dziennikarza naukowego. Podobny podział pozwala na ujęcie proponowanego tematu w sposób interdyscyplinarny. Tym samym w pracy kluczowym elementem będzie nie tyle kolejna próba zdefiniowania typu dopingu genetycznego, ile raczej wskazanie społecznej perspektywy ukazywania tego zjawiska (zob. Węziak-Białowolska, 2011).

\section{Doping: perspektywa społeczno-prawna}

Stosowanie dopingu w sporcie znane było już poprzednich epokach. Pokusa wygranej oraz chęć pokonania przeciwnika, powodowały, iż zawodnicy już w czasach starożytnej Grecji oraz Rzymu starali się w różny sposób wspomóc własny organizm (Sahaj, 2002) Zarówno w przeszłości, jak i obecnie pragnienie wygranej wzmacniane jest chęcią osiągnięcia zysku. Owy zysk związany był również (oraz nadal zapewne jest) $z$ dążeniem poszczególnych mocarstw do umocnienia swojej pozycji na arenie międzynarodowej. W historii sportu znane są w tym kontekście przypadki, zwiększania wydolności za pomocą całkowicie „fizjologicznych" metod. Jak wskazuje Tomasz Janus, „Skrajną postać [...] doping przyjął w Niemieckiej Republice Demokratycznej. W drugiej połowie XX w. w NRD powstał centralny, sterowany przez instytucje państwowe system, którego zadaniem było masowe wykorzystanie środków i metod dopingujących w celu odnoszenia sukcesów przez sportowców na arenie międzynarodowej. W tym celu wykorzystywane były między innymi środki pobudzające i znieczulające (głównie na bazie amfetaminy), testosteron oraz jego pochodne, czy tzw. baby-doping, który zakładał wykorzystanie skrajnej mobilizacji organizmu w okresie wczesnej ciąży, który miał przypadać na czas najważniejszych startów. Po zawodach sportowych zawodniczki poddawane były aborcji” (Janus, 2012). 
Obserwując aktualnie zjawiska, jakie towarzyszą większym imprezom sportowym, dojść można do wniosku, iż od dłuższego czasu - paradoksalnie sport w trakcie zmagań olimpijskich zaczyna odgrywać coraz mniejszą rolę. Do głosu zaczęli bowiem dochodzić przede wszystkim menadżerowie wielkich korporacji dostrzegający możliwość reklamowego dotarcia do - czasem milionów - widzów podziwiających "herosów sportu”. Jak wiadomo pieniądze nie omijają również samych sportowców oraz licznej ekipy specjalistów wspierających zawodników. Stąd tez aspekt ekonomiczny wygranej jest coraz istotniejszym elementem $\mathrm{np}$. zmagań atletycznych (Głowacka, Stradowski, 2002, audio).

Obawy związane z pojawieniem się propozycji oraz działań naruszających zasady etyczne sprawiło, iż od wielu już lat $w$ sporcie obowiązują formalnoprawne dokumenty odnoszące się do zakazu stosowania dopingu. W tym miejscu warto zwrócić uwagę, że poszukując informacji dotyczącej genetycznego dopingu, natrafić można na podobne legalne zakazy.

W pierwszym rzędzie zasadne jest, by wyjaśnić, jak aktualnie definiowana jest taka forma wzmacniania organizmu sportowców. Dopingiem genetycznym określamy technikę mającą na celu wsparcie organizmu zawodnika poprzez manipulację jego materiałem genetycznym. Aktualnie wyróżnia się trzy metody podobnych działań. W pierwszym rzędzie mowa jest o stymulacji ekspresji genów, prowadzącej do zwiększenia liczby komórek w organizmie, zwłaszcza komórek odpowiedzialnych za budowę poszczególnych mięśni. Istnieje również możliwość wszczepienia wcześniej wyhodowanych obcych tkanek, które następnie namnażają się w organizmie sportowca. Ponadto pojawiła się również możliwość podania zawodnikowi określonych zmodyfikowanych bakterii, wpływających na produkcję istotnych dla organizmu hormonów (np. wzrostu). Jak konkluduje w tym kontekście Grzegorz Wróbel, „Międzynarodowa Agencja Dopingowa (WADA) określa doping genetyczny/doping komórkowy jako »nie terapeutyczne« użycie genów, elementów genetycznych/komórek, które zwiększają wydajność fizyczną zawodnika”. Jak dodaje wspomniany autor, „Sfera dopingu genetycznego to swoiste przedłużenie klasycznego dopingu, który zajmował ludzkie umysły od setek lat. W obecnym świecie doping genetyczny $\mathrm{i}$ jego zakazane sfery odnoszą się zwłaszcza do ludzkiego hormonu wzrostu (HGH), insulinopodobnego czynnika wzrostu (IGF-I), erytropoetyny (EPO), miostatyny czy endotelialnego naczyniowego czynnika wzrostu (VEGF) i innych." (Wróbel, 2015, online).

Odnosząc się w tym miejscu do określonych zakazów związanych z podobnymi intencjonalnymi modyfikacjami, warto wskazać na konkretne zapisy odnoszące się do powyższego tematu. W punkcie M3 Światowego Kodeksu Antydopingowego wskazano, że „Następujące działania, mające potencjalną zdolność do poprawy wyników sportowych, są zabronione: 1 . Transfer polimerów kwasów nukleinowych lub analogów kwasu nukleinowego; 2. Użycie komórek prawidłowych lub zmodyfikowanych genetycznie". W punkcie 2 odnoszącym się do zagadnienia hormonu wzrostu podkreślono, że zabroniony jest „każdy inny czynnik wzrostu wpływający na mięsień, syntezę/degradację białka ścięgna lub więzadła, unaczynienie, zużytkowanie energii, zdolność regeneracyjną lub zmianę typu włókien." (Światowy kodeks..., 2015, s. 4, 7). Powyższe przepisy zostały implementowane 
między innymi przez Polski Związek Piłkarzy, Komisję ds. Zwalczania Dopingu w Sporcie. W przygotowanym przez wspomniane organizacje poradniku przypomniano ponadto, iż stosowanie dopingu jest w Polce zakazane nie tylko na poziomie zasad określanych przez poszczególne korporacje zawodowe. Na podobny zakaz wskazują ponadto bezpośrednio przepisy ustawy o sporcie oraz pośrednio ustawy o prawie farmaceutycznym oraz o przeciwdziałaniu narkomanii. (Poradnik antydopingowy..., 2015).Wracając jednak do interesującego nas w tym miejscu dopingu genetycznego, brak jest w tym względnie odrębnych, obszernych unormowań. Zagadnienie to nie zostało jednak opisane w raporcie antydopingowym wydanym w 2013 roku przez ww. Komisję ds. Zwalczania Dopingu w Sporcie. (Raport antydopingowy..., 2013).

\section{Istnienie - brak istnienia}

Jak podkreśla Piotr Stępień, genetyk z Uniwersytetu Warszawskiego oraz Polskiej Akademii Nauk, z analizą omawianej formy dopingu istnieje pewien problem. Coraz więcej specjalistów wspomina bowiem o prawdopodobnym istnieniu technik biologicznego wspomagania zawodników. Przy okazji publikacji dotyczących omawianego tematu pojawiają się słowa takie, jak „chyba, możliwe, prawdopodobnie, są pewne podejrzenia". W opinii wspomnianego naukowca przyczyna podobnego stanu leży przede wszystkim w charakterze potencjalnej metody genetycznego wspomagania sportowców. Omawiana forma dopingu prawdopodobnie korzysta z technik wypróbowywanych w coraz bardziej zaawansowanych formach terapii genowej (Głowacka, Stępień, 2012, online). Istota wspomnianej formy leczenia od początku opierała się na wprowadzeniu do organizmu pacjenta prawidłowej kopii danego genu. Jak dodają Sylwia Rzońca oraz Maciej Małecki, „W celach terapeutycznych zaczęto wprowadzać do komórek nie tylko prawidłowe kopie genów, których funkcja została zaburzona przez wystąpienie mutacji, ale także dodatkowe kopie genów, kodujących białka o charakterze leczniczym" (Rzońca, Małecki, 2009, s. 61). Pierwotnie działania te podejmowane były w przypadku chorób, w których diagnoza wskazuje na uszkodzenie wyłącznie jednego genu (np. mukowiscydoza). Obecnie „Rozwój badań nad molekularnymi mechanizmami powstawania chorób umożliwił zastosowanie genoterapii również w przypadku schorzeń, których przyczyną są zmiany w wielu genach (np. choroby wieńcowo-naczyniowe, AIDS, choroby ośrodkowego układu nerwowego czy nowotwory)" - podkreślają badacze (Rzońca, Małecki, 2009, s. 61) Paweł Kaliszewski uzupełnia powyższe: „Terapie genowe można podzielić na terapie wykonywane in vivo oraz ex vivo. W terapiach in vivo materiał genetyczny podaje się bezpośrednio do organizmu człowieka w celu osiągnięcia pożądanego efektu. Natomiast terapie ex vivo polegają na pobraniu komórek z organizmu ludzkiego, a następnie ich modyfikacji genetycznej w probówce i wprowadzeniu zmienionych komórek z powrotem do organizmu" (Kaliszewski, Barys, Majewska, 2013, online). 
Zdaniem Piotra Stępnia działania "genodopingowe” mogą odbywać się za pomocą interwencji o podobnym charakterze. Dzięki zrekombinowanym wirusom ekspert dąży do włączenia / wyłączenia genu odpowiadającego za daną cechę istotną ze względu na sportowe wyniki. W opinii naukowca, gdyby udało się np. wyłączyć gen kodujący miostatynę - białko odpowiedzialne za zahamowanie wzrostu mięśni - wówczas w krótkim czasie sportowiec uzyskałby masę mięśniową konieczną w danej dyscyplinie. Stępień podkreśla, iż sprawny genetyk jest $w$ stanie dostrzec modyfikacje, jakim uległ konkretny człowiek, pod jednym jednakże warunkiem. Musi wiedzieć, gdzie szukać zmian w organizmie danego człowieka. W wypadku dopingu genetycznego najczęściej nie mamy jednak takiej wiedzy. Tak jak wspomniano, potencjalne metody opierają się na modyfikacjach opartych na wykorzystaniu zrekombinowanych wirusów potrafiących wywołać odpowiedź immunologiczną organizmu. Nie wiadomo jednak, czy modyfikacji uległa dana partii mięśni, czy tez wprowadzono środek wzmagający produkcję czerwonych krwinek. Poza tym pojawia się w tym miejscu istotne pytanie o charakterze prawno-medycznym: w jaki sposób zbadać organizm zawodnika pod kątem ewentualnych zmian? Stępień słusznie zwraca w tym miejscu uwagę, że $z$ całą pewnością nie do zaakceptowania byłaby sytuacja, aby komisje antydopingowe powszechnie stosowały w wioskach olimpijskich inwazyjne metody w postaci pobrania np. fragmentów mięśni (Głowacka, Stępień, 2012, online) Mniej trudności w zlokalizowaniu omawianych zmian dostrzega Paweł Kaliszewski, członek olimpijskich zespołów antydopingowych w Londynie oraz Soczi. Twierdzi on, że wykrycie dopingu genetycznego jest coraz częściej możliwe z racji na ukierunkowanie poszukiwań właśnie w stronę podobnych modyfikacji. „Jednym z przykładów jest wykrywanie dopingu genowego z użyciem genu kodującego erytropoetynę. Badania prowadzone na makakach pokazują, że erytropoetyna produkowana przez mięśnie, na skutek przeprowadzonej uprzednio terapii genowej, różni się wzorem glikozylacji od tej produkowanej naturalnie przez nerki" (Kaliszewski, 2013, s. 7). Tym samym obecnie stosowane testy antydopingowe są w stanie wykryć modyfikacje w zakresie formy łączenia się węglowodanów z innymi związkami organicznymi. Jak dodaje, obecnie trwają prace nad testami pozwalającymi na wykrycie nawet po pięciu miesiącach celowo zmodyfikowanych zmian genetycznych. Badacz ten wskazał jednak, że do tej pory nie stwierdzono ani jednego przypadku zastosowania podobnej formy dopingu (Barys, Majewska, Kaliszewski, 2013, online).

\section{Wspomaganie dopingu}

Zmagania sportowe w obecnej postaci coraz częściej przybierają postać wyczynów, które w istocie obce są ludzkiemu organizmowi. Coraz częściej trenerzy (oraz działacze sportowi) walczą, by ich zawodnicy bili rekordy nie o kolejne minuty, ale sekundy. Nad powyższym procesem czuwają już nie tylko fizjolodzy i masażyści, ale również psycholodzy. Jak podkreśla Jan Blecharz, zawodnik jest 
w stanie osiągnąć sukces jedynie wówczas, gdy będzie przygotowany w sposób kompleksowy. Z jednej strony jest to zatem trening sprawnościowy oraz działania mające na celu wzrost wydolności organizmu, z drugiej zaś - musi on zadać sobie pytanie: czemu trenuję?, czym jest dla mnie sport? Innymi słowy - zdaniem wspomnianego psychologa pracującego między innymi z Adamem Małyszem każdy zawodnik musi wypracować niejako własną filozofię sportowej aktywności. Przyjęcie założenia, że „sport jest wyłącznie zawodem”, najprawdopodobniej nie przyniesie sukcesu. Zdaniem Blecharza nie ma możliwości oddzielenia aktywności sportowej od codziennego funkcjonowania; tym samym trening nieuchronnie związany jest ze swoistym autowychowaniem. Brak pracy nad wadami (np. niezorganizowanie, marnowanie czasu itd.), przenosi się na aktywność sportową i wprost wpływa na wyniki (Pomarnacki, Blecharz, 2002).

Podobne działania nie ominęły również dyscyplin grupowych. Jak podkreśla Jan Stradowski, kierujący pracami polskiej edycji magazynu „Focus”, w siatkówce oraz koszykówce dochodzą do głosu informatycy, a także socjolodzy, którzy bazując na odpowiednich programach, na bieżąco analizują zachowanie i strategie przeciwnej drużyny (Głowacka, Stradowski, 2012, audio). W tym miejscu nie można zapomnieć o specjalistach włókiennictwa, którzy co roku zaskakują nowymi propozycjami kombinezonów, butów czy też bluzek, które mają współgrać z ciałem sportowca. Jak relacjonował w 2012 roku Tomasz Rożek, jedna z czołowych światowych firm „[...] z myślą o biegaczach wyprodukowała buty [...], których inspiracją są... mosty wiszące. Podeszwa podtrzymywana jest jak gdyby niezależnie od boków. W efekcie podeszwa znacznie lepiej dostosowuje się do kształtu stopy. I jeszcze jedno. Taki but waży mniej niż 100 gramów" (Rożek, 2012, s. 23). Wspomniany fizyk, a zarazem dziennikarz naukowy, dodaje ponadto, że w amerykańskiej lidze piłki nożnej wprowadzono koszulki dla zawodników, w które wszyte są czujniki na bieżąco informujące trenera o stanie zdrowia piłkarza. Tym samym istnieje możliwość podjęcia decyzji dotyczącej zmiany zbyt zmęczonego zawodnika (Rożek, 2012). Podobne techniki mają na celu zmniejszenie do minimum stopnia oddziaływania zewnętrznych czynników mogących w sposób negatywny wpływać na ostateczny wynik. Mowa w tym miejscu z jednej strony o oporze powietrza, z drugiej wskazuje się na stan sportowca i kluczowy charakter wiedzy dotyczącej jego aktualnej dyspozycji psychofizycznej. Warto tutaj dodać, że doping genetyczny ma zupełnie inny cel. Od tej formy oczekuje się, iż niejako od wewnątrz wspomoże naturalne zdolności lub też możliwości ludzkiego ciała.

\section{Perspektywa etyczna}

Pojawiające się w mediach informacje o dopingu najczęściej powiązane są z negatywnymi ocenami. Nie tylko etycy, ale i sami sportowcy podkreślają, że jest to $w$ istocie droga na skróty. Wskazuje się z jednej strony na brak uczciwości. Pojawiają się również opinie, iż sztuczne wspomaganie np. wydolności jest de facto oszukiwaniem samego siebie. Grzegorz Bielec badający postawy pływaków 
wobec dopingu, odnotował takie opinię zawodników na temat wspomnianego zjawiska: „Sport powinien być czystą rywalizacją”; „Jest to oszukiwanie siebie i innych”; „Jest to nieuczciwe wobec przeciwników”; „każdy sportowiec musi poznać granicę swoich możliwości” (Bielec, 2005, s. 57). Potwierdzają one aktualność istniejących od czasów starożytnych Aten zasad wskazujących, iż zawodnik nie tylko walczy z konkurentami, ale podejmuje walkę również z samym sobą, własnymi ograniczeniami, ułomnościami, obawami itd. Stosując doping, oszukuje wpierw samego siebie. Nie jest w stanie poznać nie tylko własnych ograniczeń, ale również możliwości. Osiągane rezultaty nie wynikają bowiem z jego zdolności. Zostały one „udoskonalone" w sposób biologiczny lub genetyczny.

Okazuje się jednak, że zarówno ze strony biologów jak i bioetyków spotkać można pozytywne opinie dotyczące genetycznego wspomagania organizmu zawodników. Zdaniem cytowanego powyżej Piotra Stępnia doping genetyczny nie jest niczym innym, jak testowaniem najnowszych osiągnięć medycyny w warunkach, w których dana osoba wyraża na powyższe zgodę. Wspomniany naukowiec doskonale zdaje sobie sprawę, iż mistrzostwa oraz olimpiady nie są już sportowym spektaklem, lecz stanowią one coraz częściej arenę zmagań nauki oraz biznesu. Terapia genowa czy też medycyna spersonalizowana wzbudzają jednak ogromną nadzieję na rozwiązanie licznych problemów zdrowotnych dotyczących konkretnej osoby. Stadion sportowy staje się w tym ujęciu nową formą naturalnego laboratorium (Głowacka, Stępień, 2012, online). Podejście prezentowane przez wspomnianego genetyka można porównać z wprowadzeniem na rynek innowacji technologicznych, które wpierw testowali pierwsi astronauci.

Interesujące jest, iż także bioetycy nie odrzucają arbitralnie podobnych metod. Zdaniem ks. Tomasza Kraja "Jeśli mamy do czynienia z manipulacją przypominającą terapię genową linii somatycznej oraz spełnione są pewne warunki, to również $\mathrm{i}$ te ingerencje byłyby do zaakceptowania. Granicą takiego ulepszania jest cnota, tj. sposób, w jaki człowiek osiąga doskonałość w działaniu jako osoba”. W opinii naukowca „Jeśli proponowana ingerencja np. mająca na celu przedłużenie ludzkiego życia, nie przeszkadza w wysiłku zmierzającym do osobowego spełnienia, ani w osiągnięciu cnoty i jeśli spełnione są także inne warunki (bezpieczeństwo interwencji, poinformowana zgoda, poprawna intencja, etc.), to także ona może zostać zaaprobowana" - podsumowuje bioetyk (Kraj, Kmieciak, 2013, online). Opinie ks. Kraja zainteresowały dziennikarzy naukowych tygodnika "Gość Niedzielny”, którzy wskazali, iż analizując podobne dylematy etyczne naukowiec ten „[...] przytacza przykład słynnego amerykańskiego golfisty Tigera Woodsa. Wykorzystał on techniki okulistyczne, dzięki czemu jego wzrok jest ostrzejszy niż u człowieka o zdrowych oczach. Pomaga mu to w trafianiu golfową piłeczką do dołka. Gdyby taki efekt uzyskano na drodze manipulacji genetycznej, to - zdaniem bioetyka z Krakowa - byłoby to możliwe do zaakceptowania. O ile, oczywiście, spełniałoby warunki o charakterze bardziej podstawowym, takie jak bezpieczeństwo procedury dla zdrowia i zgoda człowieka, który się jej poddaje. W grę mogłyby tu wchodzić także zasady fair play danej dyscypliny sportu" (Dudała, Rożek, 2011, online).

Wydaje się jednak, iż pomimo powyższych dość pozytywnych opinii odpowiedź na pytanie dotyczące godziwości stosowania genetycznego dopingu 
posiada charakter negatywny. W pierwszym rzędzie należy bowiem zwrócić uwagę na cel podobnych interwencji. Nie jest nim leczenie danej osoby (lub też, jak u wspomnianego golfisty, naturalne usprawnianie organizmu), ale wyłącznie zwiększenie jej konkretnych umiejętności lub zdolności. Cechy te nie są w tym przypadku obarczone jakimikolwiek funkcjonalnymi anomaliami. Sportowiec (lub trener, działacz itd.) oczekuje jednak, iż „od wewnątrz" wspomożona zostanie jego siła oraz wydolność. W tym miejscu na nowo napotykamy sprzeczność, która przybrać może również postać swoistej iluzji. Sportowiec stosując np. chemiczne „wspomagacze” ma świadomość, iż z zewnątrz dopomaga własnemu ciału. Doping genetyczny ma zniwelować podobne negatywne wrażenie. Zmodyfikowany genetycznie organizm ma sam zwiększać np. siłę zawodnika. Negatywny osąd stosowania środków chemicznych może nie występować w przypadku wsparcia genetycznego, uznawanego za naturalne. Inna ocena podobnego zjawiska byłaby w chwili np. użycia podobnych technik w przypadku zaburzeń związanych z napięciem mięśniowym. Eksperymentalne badania na myszach dotyczące wprowadzenia do ich organizmów zmodyfikowanych genetycznie preparatów białkowych wykazały, iż prowadzą one między innymi do odbudowania sprawności starych mięśni u poszczególnych osobników, jednocześnie zwiększając ich wydolność. Użycie jednak podobnej techniki w sporcie całkowicie zaburza proces inteligibilności, a więc powiązania pracy, treningu oraz wysiłku z realnymi osiągnięciami, rezultatami oraz sukcesami (Kraj, 2010).

Dokonując oceny etycznej omawianej formy dopingu zasadne jest, by zaznaczyć, iż odnosi się on do szerszego zjawiska określanego mianem „ulepszania człowieka". Bazując na zdobyczach genetyki, działanie to podejmowane jest w celu zwiększenia naturalnych możliwości, jakie posiada człowiek. Jak podkreśla Barbara Chyrowicz, wyróżniamy ulepszanie zdrowotne, czyli terapię, oraz to, które nie odnosi się do ludzkiego zdrowia. Badaczka zwraca uwagę, iż pojawiają się obecnie również propozycje ulepszania moralnego, opierającego się na redukcji agresji oraz stymulowaniu emocji. Zdaniem Chyrowicz idea „ulepszania” człowieka wiąże się z licznymi obawami. W pierwszym rzędzie podejmowanie podobnych działań to w istocie „wchodzenie w rolę Boga”, bez względu na sposób Jego definiowania. Argument ten ściśle wiąże się $z$ ingerencją w naturę, która kryje przed człowiekiem wiele tajemnic. Nie możemy być pewni bliższych oraz dalszych konsekwencji stosowania dopingu genetycznego. Warto także zwrócić uwagę na niebezpieczeństwo pojawienia się pokusy tworzenia swoistych „dzieci projektów". Wpierw postępowanie to opierać się może na chęci wyeliminowania w fazie zarodkowej konkretnych wadliwych genów, z czasem jednak pojawić się może pokusa tworzenia „super dziecka”. Niczym na równi pochyłej, powstawać mogą kolejne, coraz śmielsze propozycje. Ostatnie uwagi, również odnoszące się do dopingu genetycznego związane są z odpowiedzialnością za przyszłe pokolenia. Genetycy nie wiedzą, jak na populacje wpłynąć mogą coraz częstsze sztuczne modyfikacje. Ponadto należy zaznaczyć, że wspomniane modyfikacje posiadają niepewny charakter i wiązać się mogą z wystąpieniem istotnego niebezpieczeństwa (Chyrowicz, 2013). Opinie tę potwierdza wspomniany Paweł Kaliszewski, który zwraca uwagę, że „Badania na modelach zwierzęcych wskazują 
na to, że zastosowanie dopingu genetycznego wiąże się z ogromnym ryzkiem dla zdrowia i życia, [...] Nawet przy założeniu, że sportowiec mógłby sam zaopatrzyć się w preparaty umożliwiające wprowadzenie do organizmu obcego DNA, ich zastosowanie obarczone jest ryzykiem wystąpienia wielu nieprzewidywalnych komplikacji, na przykład silnej odpowiedzi immunologicznej" (Kaliszewski, 2013, s. 7). Badacz ten wskazuje, iż dyskusja na temat dopingu genetycznego częstokroć pomija istotny fakt dotyczący konieczności traktowania ludzkiego organizmu jako całości. Jak wskazuje Kaliszewski: „Nawet, jeśli mamy zamiar spowodować w wyniku dopingu genetycznego tylko zwiększoną produkcję konkretnego hormonu (np. hormon wzrostu lub EPO), musimy liczyć się z niezamierzonym wpływem terapii na inne tkanki organizmu - na przykład gwałtowne przyspieszenie utajonego procesu nowotworowego" (Kaliszewski, 2013, s. 7).

\section{Wnioski}

Podejmując próbę sformułowania końcowych wniosków, odnoszących się do zaprezentowanych powyżej rozważań, warto dokonać ich usystematyzowania.

1. Aby doping genetyczny mógł być uznany za metodę moralnie godziwą bądź też niegodziwą, wpierw społeczność sportowa musi mieć pewność, iż podobne działania są w ogóle podejmowane. Obecnie mamy podejrzenia, nie mamy jednak pewności. W następnej kolejności warto rozważyć, czy terapia genowa linii somatycznej, (na której opierać ma się ww. forma dopingu) jest metodą bezpieczną. Niemniej ważna wydaje się wątpliwość związana z elementarną uczciwością sportowych działań. Istnieje bowiem obawa, iż wykorzystanie genetyki w sporcie sprawi, iż niebawem okaże się, że w istocie nie liczy się, jak ciężko sportowiec pracował, ile wysiłku włożył w osiągnięcie rekordu. Liczyć się będzie natomiast (już powoli obserwujemy podobne zjawisko), w jaki strój jest ktoś ubrany oraz jak inteligentni są jego biofizjologiczni doradcy. Jak wskazuje Jan Stradowski, w dyscyplinie, jaką jest np. podnoszenie ciężarów już dzisiaj obserwujemy pojawienie się legalnej, a jednocześnie budzącej wątpliwości etyczne metody działań: zawodnicy podnoszący ciężary korzystają coraz częściej z koszulek wyprodukowanych z tworzywa, które działa niczym sprężyna. W chwili, gdy sportowiec podnosi sztangę, koszulka w pewnym sensie „odbija” jej ciężar od klatki piersiowej (Głowacka, Stradowski, 2002, audio).

2. Próbując odpowiedzieć na pytanie: czym w istocie jest doping genetyczny?, otrzymujemy coraz dokładniejsze informacje. Powoli potrafimy opisać formy wykorzystania technik modyfikacyjnych ludzki organizm w celu zwiększenia jego naturalnych możliwości. Element powodujący zmianę może być modyfikowany od wewnątrz. Istnieje jednak również możliwość zewnętrznego działania, które opiera się na wykorzystaniu zrekombinowanych wirusów, które prowadzić będą np. do zwiększenia wydzielania się określonego hormonu (np. wzrostu). Pojawienie się podobnych 
możliwości spowodowało konieczność zmiany przepisów antydopingowych. W tym jednak momencie trudno jest stwierdzić, czy aktualne formalne rozwiązania w pełni odzwierciedlają zjawisko dopingu genetycznego, który jak wspomniano, nie został jeszcze w pełni poznany.

3. Szukając odpowiedzi na pytanie: czym grozi stosowanie genetycznych technik modyfikacji organizmów sportowców? warto zwrócić uwagę na kilka elementów. W pierwszym rzędzie mowa w tym miejscu o zagrożeniach zdrowotnych. Każda forma wspomagania organizmu w sposób chemiczny lub genetyczny łączy się z niebezpieczeństwem dla organizmu. Doping o podobnym charakterze posiada $w$ istocie formę eksperymentu, w którym potencjalnie brać udział mogą sportowcy. Nie znamy obecnie bliższych oraz dalszych konsekwencji celowej zmiany funkcjonowania organizmu w jego tak wrażliwym elemencie, jaki ludzki genotyp. Brak jest również wiedzy dotyczącej wpływu podobnych modyfikacji na kolejne pokolenia. Wyrażona przez Piotra Stępnia pozytywna ocenę podobnej formy dopingu musi być w tym miejscu poddana krytyce. Zakładając, iż zawodnik wyraził zgodę na tego typu interwencję, trudno w tym miejscu nie mieć obaw odnośnie do jakości owej zgody. Zgodnie z utrwaloną w doktrynie prawno-medycznej zasadą, by zgoda danej osoby była w pełni kompetentna, wpierw musi być ona poinformowana o celu, przebiegu procedury medycznej oraz jej pozytywnych i negatywnych konsekwencjach (Sztycherz, 2008). W omawianej sytuacji, jak wskazano, nie mamy aktualnie wiedzy dotyczącej konsekwencji modyfikacji ludzkiego organizmu.

4. Nie można w tym miejscu pominąć również innych, mniej widocznych konsekwencji. Starając się odpowiedzieć na tytułowe pytanie: Czy doping genetyczny zmieni sportowe prawa?, należy wskazać, na niebezpieczeństwo redefinicji zjawiska sportu. Zmagania sportowe, trening, doskonalenie itd. to czynności, których celem jest nie tylko zdobycie olimpijskiego złota. Jak wskazał ks. Tomasz Kraj, obecnie odbywające się olimpiady oraz mistrzostwa powodują, iż u sportowców, trenerów i działaczy pojawia się pokusa, by, „jak najszybciej” osiągnąć ,jak najwięcej”. Podobne terminy są jednak niezwykle nieostre. Czy nie będą one bowiem sukcesywnie przesuwane? Czy sportowiec w podobnych działaniach jest nadal podmiotem, czy też staje się przedmiotem i dodatkiem do konkretnych działań sportowego sztabu? (Kraj, 2010) Pojawia się w tym miejscu pytanie o utrwaloną w sporcie zasadę fair play. Wprowadzenie możliwości stosowania genetycznego dopingu lub też jego akceptacja całkowicie anuluje podobne fundamentalne założenie. Kluczowym elementem staje się innowacyjny pomysł modyfikacyjny, który zastępuje pracę oraz trening zawodnika (Chyrowicz, 2004).

5. Pojawienie się w sporcie dopingu genetycznego wpłynie (lub wpływa?) na pojawienie się licznych zmian. Zmienia się organizm człowieka, możliwości działania sportowca, a także zasób wiedzy naukowców oraz trenerów, dostrzegających możliwości osiągnięcia przez ich podopiecznego niespotykanych wyników. Widząc podobne modyfikacje warto jednak wziąć pod 
uwagę, że pojawienie się omawianych zjawisk może na trwałe zmienić sport, w którym trening, sprawność oraz rywalizacja będą sformułowaniami jedynie o historycznym charakterze ${ }^{2}$.

\section{Literatura}

Apanowicz J., 2002, Metodologia ogólna, Wydawnictwo Diecezji pelplińskiej „Bernardinum”, Gdynia, S. 44.

Bielec G., 2002, Wiedza i postawy pływaków wobec sportu, „Sport Wyczynowy”, nr 3/4, s. 57.

Cook R., Nano, Wydawnictwo Rebis, Poznań, 2013 r, s. 7-8.

Chyrowicz, B., Spór o poprawę ludzkiej natury, (w:) B. Chyrowicz (red.), Etyka i technika w poszukiwaniu ludzkiej doskonałości, Towarzystwo Naukowe KUL, Lublin, 2004, s. 59-61.

Chyrowicz B., 2013, Genetyka i nowe technologie, (w:) W. Chańska, J. Różańska, (red.), Bioetyka, LEX a Walters Cluwer buisness, Warszawa.

Dudała J., Rożek T., 2011, Genetyka, „Gość Niedzielny”, nr 12, s. 19.

Goodman N., 2001, Wstęp do socjologii, Wydawnictwo Zysk i S- ka, Poznań, s. 31-32.

Głowacka K., Stradowski J., 2012, Jak szybko może pobiec człowiek, Radiowa Akademia Nauk, Radio TOK.FM, Warszawa, (archiwum autora).

Głowacka K., Stępień P., 2012, Jestem za dopingiem genetycznym, Radiowa Akademia Nauk, Radio TOK.FM, Warszawa (archiwum autora).

Goban-Klas T., 1984, Analiza zawartości przekazów masowych, (w:) J. Wasilewski (red.), Wybrane zagadnienia teoretyczno-metodologiczne badań socjologicznych, Wydawnictwo UJ, Kraków.

Kaliszewski P., 2013, Wiadomości antydopingowe, Polish Commision Against Doping in Sport, Warszawa, s. 7.

Kraj T., Kmieciak B., Problem postępu naukowego, a genetyka człowieka, biotechnologia.pl, źródło: http:// biotechnologia.pl/bioetyka/aktualnosci/problem-postepu-naukowego-a-genetyka-czlowiekawywiad-z-z-ks-dr-hab-tomaszem-krajem-kierownikiem-katedry-teologii-zycia-na-wydzialeteologicznym-uniwersytetu-papieskiego-jana-pawla-ii-w-krakowie, 12970 (dostęp: 23.06.2015 r.).

Kraj T., 2010, Granice genetycznego ulepszania człowieka, Wydawnictwo św. Stanisława, Kraków.

Kmieciak B., Bioetyczny detektyw - innowacyjny projekt TV Trwam, biotechnologia.pl, źródło: http:// biotechnologia.pl/bioetyka/aktualnosci/bioetyczny-detektyw-innowacyjny-projekt-tv-trwam,536. html?mobile_view=true (dostęp: 23.06.2015 r.).

Janus T., 2012, Zjawisko agresji w widowiskach sportowych. Charakterystyka i ocena, Uniwersytet Kardynała Stefana Wyszyńskiego, Warszawa, (niepublikowana praca doktorska).

Poradnik antydopingowy, Polski Związek Piłkarzy, Komisja ds. Zwalczania Dopingu w Sporcie, ŁódźWarszawa, 2015, s. 3.

Majewska K., Barys J., Kaliszewski P., 2013, Doping genowy - jak daleko posunie się sportowiec przyszłości?, Biotechnologia.pl, źródło: http://biotechnologia.pl/biotechnologia/aktualnosci/dopinggenowy-jak-daleko-posunie-sie-sportowiec-przyszlosci-rozmawiamy-z-drem-pawlemkaliszewskim, 140 (dostęp: 23.06.2015 r.).

Pac Pomarnacki, A, Blacharz J., 2002, Psychologiczne wspomaganie w sporcie - zakres i skuteczność, „Sport Wyczynowy”, nr 3/4, s. 121-122.

Raport antydopingowy, 2015, Komisja ds. Zwalczania Dopingu w Sporcie, Warszawa.

Rzońca S, Małecki M., 2009, Proapoptotyczna terapia genowa a wrażliwość nowotworów na chemioterapię, „Współczesna Onkologia”, nr 2, s. 61.

Rożek T., 2012, Technologie sportu, „Gość Niedzielny”, nr 31, s. 23.

Sahaj T., 2002, Doping - koń trojański sportu, „Sport Wyczynowy”, nr 1/ 2, s. 446.

2 Autor wykorzystał w pracy krótkie fragmenty swojej wcześniejszej publicystycznej publikacji pt. Doping genetyczny - wiemy, że nic nie wiemy, opublikowanej na stronie biotechnologia.pl. 
Światowy kodeks antydopingowy. Lista zabroniona WADA, 2015, Standard międzynarodowy, Światowa Agencja Antydopingowa.

Sztychlerz A., 2008, Prawa pacjenta, a obowiązki lekarza. Praktyka lekarza rodzinnego, Via Medica, Warszawa, s. 399.

Węziak-Białowolska D., 2011, Operacjonalizacja i skalowanie w ilościowych badaniach społecznych, „Zeszyty Naukowe Instytutu Statystyki i Demografii SGH”, nr 16, s. 6.

Wróbel, G., Doping genetyczny, Akademia Wychowania Fizycznego, Katowice, źródło: http://www. gregfit.pl/doping_gen.pdf. (dostęp: 23.06.2015 r.). 